\title{
Reappraising Diplomacy: Structural Diplomacy and the Case of the European Union*
}

\author{
Stephan Keukeleire ${ }^{\mathrm{a})}$, Robin Thiers ${ }^{\mathrm{b})}$ and Arnout Justaert ${ }^{\mathrm{c}}$ \\ Faculty of Social Sciences, Institute for International and European Policy \\ Parkstraat 45, Bus 03602, B-3000 Leuven, Belgium \\ a) stephan.keukeleire@soc.kuleuven.be \\ b) robin.thiers@soc.kuleuven.be \\ c)arnout.justaert@soc.kuleuven.be
}

Received: 26 November 2008; revised: 18 March 2009; accepted: 31 March 2009

\begin{abstract}
Summary
Diverse shifts have taken place in both the daily practice and academic analyses of diplomacy. The authors argue that the various conceptualizations do not sufficiently take into account that diplomacy is increasingly concerned with influencing or shaping structures. The aim of this article is therefore to reappraise the nature of diplomacy in general and of the European Union in particular by elaborating on the concept structural diplomacy. This concept refers to the process of dialogue and negotiation by which actors in the international system seek to influence or shape sustainable external political, legal, economic, social and security structures at different relevant levels in a given geographic space (from the level of the individual and society, to the state, regional and global levels). The EU's institutional and diplomatic set-up allows it to conduct structural diplomacy. However, the extent and effectiveness of this diplomacy strongly differ depending on the regions in question.
\end{abstract}

\section{Keywords}

structural diplomacy, European Union, EU's pillars and institutional actors, European Commission, influencing structures, sustainability' new conceptualizations of diplomacy, diplomatic agenda, dialogue, negotiation, public diplomacy

\section{Introduction: Changing Concepts and Contexts of Diplomacy}

The traditional approach towards diplomacy has been gradually challenged, both in the daily practice of diplomacy and in the academic analyses of diplomacy, with new dimensions of diplomacy emerging and innovative conceptualizations

\footnotetext{
*) The authors are grateful to Rouba Al-Fattal (doctoral candidate at the University of Leuven), the editors of The Hague Journal of Diplomacy and the anonymous reviewers for their useful comments and suggestions. For an earlier short analysis of structural diplomacy, see Stephan Keukeleire, 'The European Union as a Diplomatic Actor: Internal, Traditional and Structural Diplomacy', Diplomacy and Statecraft, vol. 14, no. 3, 2003, pp. 31-56, that was reprinted in Wyn Rees and Michael Smith (eds.), The International Relations of the European Union (London: Sage, 2008).
} 
being developed. ${ }^{1}$ Broadly speaking, the existing literature indicates three main shifts in the institution of diplomacy. ${ }^{2}$

The first shift is related to the widening of the diplomatic agenda, 'which today encompasses anything from international debt management and telecommunications to refugee flows and the environment'. This led professional diplomats into unfamiliar territory ${ }^{3}$ and pointed to the need for expertise beyond that of diplomats. ${ }^{4}$ Diplomats increasingly had to rely on the expertise and input of civil servants and specialists from other specialized governmental actors and non-state agencies. The second shift regards the kind of actors that can conduct diplomacy and that are involved in diplomatic relations. Diplomacy was traditionally an essential institution for the conduct of inter-state relations, ${ }^{5}$ with states and their representatives as the only possible diplomatic actors, yet diplomacy now increasingly includes relations between governmental and non-governmental actors with international organizations, enterprises, non-governmental organizations (NGOs) and other non-state actors also playing a role and transforming themselves into new types of diplomatic actors. ${ }^{6}$ This has led to new labels such as private diplomacy and paradiplomacy ${ }^{7}$ and has resulted in a blurring distinction between 'what is diplomatic activity and what is not, and who, therefore, are diplomats and who are not'. ${ }^{8}$ Attention to the broader public at the receiving end of diplomacy is also growing, with the concept 'public diplomacy' referring to the importance of communicating with citizens in other states or societies. ${ }^{9}$ The third shift points to the growing importance of multilateral negotiations and organizations as a framework for diplomacy. This broadening of the practice of diplomacy has led analysts to speak of conference diplomacy, ${ }^{10}$ associative diplomacy (which is concerned with relations between regional organizations) $)^{11}$ and, particularly,

\footnotetext{
1) See Jan Melissen (ed.), Innovation in Diplomatic Practice (London: Macmillan, 1999).

2) The following overview draws largely on the overview provided by Christer Jönsson, 'Diplomacy, Bargaining and Negotiation', in Walter Carlsnaes, Thomas Risse and Beth A. Simmons (eds), Handbook of International Relations (London: Sage, 2002), p. 216.

3) Melissen, Innovation in Diplomatic Practice, p. xv.

4) Jönsson, 'Diplomacy, Bargaining and Negotiation', p. 216.

5) Ibid., p. 212.

6) Brian Hocking, 'Catalytic Diplomacy: Beyond "Newness" and "Decline", in Melissen, Innovation in Diplomatic Practice; and Michael Goodman (ed.), 'Special Issue: The Role of Business in Public Diplomacy', Journal of Business Strategy, vol. 27, no. 2, May-June 2006.

7) See Jan Melissen, 'Introduction' and Paul W. Meerts, 'The Changing Nature of Diplomatic Negotiation', in Melissen, Innovation in Diplomatic Practice.

8) Keith Hamilton and Richard Langhorne, The Practice of Diplomacy: Its Evolution, Theory and Administration (London: Routledge, 1995), p. 3. See also George F. Kennan, 'Diplomacy Without Diplomats?', Foreign Affairs, vol. 76, no. 5, 1997, pp. 198-212.

9) On public diplomacy, see Jan Melissen (ed.), The New Public Diplomacy: Soft Power in International Relations (Basingstoke: Palgrave Macmillan, 2007); and 'Special Issue: Public Diplomacy in a Changing World', The Annals of the American Academy of Political and Social Science, vol. 616, no. 1, 2008.

10) Johan Kaufman, Conference Diplomacy: An Introductory Analysis (London: Macmillan, 1996).

11) R.P. Barston, Modern Diplomacy (London: Longman, 1988), pp. 108-116.
} 
multilateral diplomacy. ${ }^{12}$ Interestingly, in the three shifts outlined here, the European Union is highly relevant, both for embodying these shifts and for de facto stimulating and strengthening them.

Another shift that receives much less attention in the literature on diplomacy is the shift in the objectives of diplomacy. Particularly since the end of the Cold War, diplomacy is increasingly not only focused on influencing inter-state relations, crises and conflicts. Diplomacy increasingly also had the objective of shaping or influencing structures, with structures being the organizing principles, rules of the game and institutions that determine how actors relate to each other in the political, economic, legal, social and security fields. We argue that diplomacy has been increasingly concerned with structures as a result of the breakdown of the East-West order from 1989-1991 and the more gradual breakdown or fading away of the Westphalian order. ${ }^{13}$ The breakdown of the old structures implied that reordering or restructuring societies, countries, regions and the international arena at large emerged as a major objective of diplomacy — in order to diminish anarchy and uncertainties and to guarantee influence and/or stability in the long term. This need to restructure became particularly pertinent for those regions and countries where longstanding structures disappeared, such as the countries that until the late 1980s were organized on the basis of communist ideology, or the countries and regions in the Mediterranean or Africa that were 'disciplined' through belonging to either the Western or Eastern camp during the East-West conflict. Within this changing context, the capacity to 'structure' other countries, regions and the global environment and to influence long-term structural changes became and remains critical.

In order to facilitate the analysis of diplomacy that is primarily focused on shaping or influencing structures, we suggest labelling and conceptualizing this diplomacy as structural diplomacy. We include the term 'structural' in the concept as an important and necessary addition because 'what is not named largely remains unnoticed. ${ }^{14}$ The section below treats the question of what structural diplomacy actually is, while the subsequent section analyses the structural diplomacy of the EU.

\footnotetext{
12) James P. Muldoon et al. (eds), Multilateral Diplomacy and the United Nations Today (Boulder CO: Westview, 1999). See the articles by Jørgensen ('The European Union in Multilateral Diplomacy', pp. 189-209) and Smith and Hardacre ('The European Union and the Diplomacy of Complex Interregionalism', pp. 167-188) in this special issue of The Hague Journal of Diplomacy, vol. 4, no. 2.

13) Stephan Keukeleire and Jennifer MacNaughtan, The Foreign Policy of the European Union (Basingstoke: Palgrave, 2008), pp. 14-18.

14) Gil Friedman and Harvey Starr, Agency, Structure, and International Politics: From Ontology to Empirical Inquiry (London: Routledge, 1997), p. 30.
} 


\section{Structural Diplomacy}

\section{Conceptualizing Structural Diplomacy}

Structural diplomacy refers to the process of dialogue and negotiation by which actors in the international system seek to influence or shape sustainable external political, legal, economic, social and security structures at different relevant levels in a given geographic space (from the level of the individual and society, to the state, regional and global level). ${ }^{15}$ The term structural refers to two key aspects: the objective to have an effect on structures; and the objective to have effects that are sustainable.

First, the qualification 'structural' refers to the objective to influence or shape structures. These structures consist of organizing principles, rules of the game and institutions that shape and order the political, legal, economic, social and security fields in a given geographical space. Structures entail both general organizing principles and rules of the game (such as 'capitalism', 'democracy', 'rule of law' or 'peaceful resolution of conflicts') and the operationalization of these principles through a complex constellation of institutions, laws and habits, etc. ${ }^{16}$ The purpose of structural diplomacy is to change or strengthen these specific constellations of rules of the game, institutions, laws and habits in a country or, more far-reaching and ambitious, to promote the adoption of new organizing principles (such as 'democracy' in the case of a non-democratic country) and the subsequent operationalization of these principles. When systemic changes occur (as was the case with the fall of communism in 1989-1991) or a vacuum exists (for instance after a war, such as after the Second World War, the Balkan Wars or the War in Iraq), the objective of a structural diplomacy can be to shape new structures. When a more or less established set of structures already exists in a specific geographic setting, the objective of structural diplomacy will be to influence these structures. This analysis mainly presents structural diplomacy as aiming at structural changes. However, structural diplomacy can also aim at assuring structural

15) The first words of this definition are taken from the general definition of 'diplomacy' by Adam Watson: 'the process of dialogue and negotiation by which states in a system conduct their relations and pursue their purposes by means short of war'. See Adam Watson, Diplomacy: The Dialogue between States (London: Eyre Methuen, 1982), p. 10.

16) This also points to the difference between structural diplomacy and development cooperation or development policy. The latter are in the first place focused on poverty reduction and other UN Millennium Development Goals. Traditionally, the development cooperation approach of the EU and European countries was to pursue these goals within (and thus without questioning) the existing political, economic and security structures of the third country. However, this development policy/cooperation increasingly obtained a structural dimension, with Western actors in their contacts with Southern countries increasingly pointing to the need to pursue structural changes as a complement to or condition for development aid. To the extent that this is the case, development policy remains distinct but can nevertheless be part of a structural diplomacy. See Keukeleire and MacNaughtan, The Foreign Policy of the European Union, pp. 215-216. 
stability, status quo and continuity. The objective is then to support and maintain existing structures and to avoid structural changes from occurring.

Second, the qualification 'structural' refers to the objective of having effects that are sustainable. The structures that are pursued should not only be viable in the short term, but should equally be sustainable in the long term, including when the intensity of the structural diplomacy diminishes or when activities in the context of structural diplomacy are concluded. The purpose of the process of dialogue and negotiation is thus not simply to shape or influence structures, but to shape or influence structures in such a way that these structures obtain an enduring character and become relatively permanent. Only then does it become possible to speak of structural changes or structural reforms caused by structural diplomacy (alongside other factors, as discussed below). Both material and immaterial or ideational factors can contribute to the sustainability of structures and thus to the long-term success of a structural diplomacy: the material factors are related to the practical operationalization and functioning of the structures that are promoted and to the context in which they are embedded; the immaterial factors are related to issues such as the interiorization of principles, legitimacy and to what we label 'mental structures'. These various factors are discussed in the following section, as they affect a structural diplomacy's chance of success.

The example of democracy can help to illustrate the difference between the two key aspects of 'structural' (that is, the one concerned with shaping or influencing structures and the one concerned with assuring that these structures are sustainable). Structural diplomacy towards a third country can lead it to adopt democracy as the basic principle of its political structures and to translate this principle in the constitutional and institutional set-up of the country: through the inclusion of democratic principles in the country's constitution; the creation of and support for political parties; the organization of free elections; and support for the functioning of the parliament, etc. (the first key aspect). But the central question is how this structural diplomacy can help to ensure that these democratic structures will be able to function properly in the long term. And this will also depend on the wider context (that is, the existence of a free press and respect for the division of legislative, executive and judicial power, etc.) and on the extent to which the democratic rules of the game are considered as the normal way to organize politics by both the elites and the population (the second key aspect). Only then will democracy become 'the only game in town' and is it possible to speak of a 'consolidated democracy'. ${ }^{17}$

\footnotetext{
17) See Juan Linz and Alfred Stepan, Problems of Democratic Transition and Consolidation (Baltimore MD: Johns Hopkins University Press, 1996). Linz and Stepan speak of different 'arenas of democracy' (civil society, political society, rule of law, state bureaucracy and economic community). In order for a democratic 'transition' to be sustainable and become 'consolidated', the relevant conditions in all of these arenas need to be fulfilled.
} 


\section{Factors Contributing to Effectiveness}

This section identifies a (non-exhaustive) set of possible factors that contribute to effectiveness and success, including both material and immaterial conditions such as intensity of interaction, long-term approach, comprehensiveness, embeddedness within broader structural and traditional foreign policy initiatives, and legitimacy. These factors can be seen as a set of hypotheses that have to be confirmed (or rejected) through further empirical research. ${ }^{18}$ In the framework of this article, we focus mainly on conditions for effectiveness of a structural diplomacy that is focused on the state level. ${ }^{19}$

Intensity points to the active approach that is required in structural diplomacy and that implies more than a merely ritual repetition of general values and principles. One might indeed observe that the promotion of rule of law and human rights, etc., is the subject of many diplomatic actions by the West and the EU in particular. However, these are very often the subject of a merely declaratory diplomacy, which is not supported by an active process of dialogue and negotiation that is aimed, first, at convincing other actors about the need, desirability and feasibility of creating or changing the various relevant structures and, second, at supporting, advising and steering them in translating general organizing principles into concrete institutions and rules. In other words, in order to speak about a structural diplomacy, it is not sufficient for a diplomatic actor to repeat unilaterally in every declaration that a third actor should comply with some standards, but rather it requires this diplomatic actor to interact actively and on a continuous basis with this third actor to promote the desired structural changes. Intensity also implies that the frequency and profundity of contacts between the actors that are involved in structural diplomacy need to be high. It also implies that dialogue is needed with a wide range of actors in the third country, as the goal is not only to convince diplomatic and political counterparts about the general principles of the proposed structural changes, but also to interact with those responsible for translating these principles into concrete operational terms. There is consequently not only a need for intense contacts at a high political and diplomatic level, but also at other levels — such as lower governmental officials, technical experts,

18) These factors are identified on the basis of both earlier and ongoing research. For earlier research, see Stephan Keukeleire, Het buitenlands beleid van de Europese Unie (Deventer: Kluwer, 1998); and Keukeleire and MacNaughtan, The Foreign Policy of the European Union, pp. 215-216. Ongoing research includes the analysis of the EU's structural foreign policy in two specific cases: Kosovo; and the Democratic Republic of Congo. See Stephan Keukeleire and Robin Thiers, 'Reconceptualizing (European) Foreign Policy: The EU's Structural Foreign Policy towards Kosovo', in Panos Koutrakos (ed.), The European Union in the World: Legal and Political Perspectives (forthcoming).

19) For the global level, see Stephan Keukeleire and Simon Schunz, 'Foreign Policy, Globalization and Global Governance: The European Union's Structural Foreign Policy', paper prepared for the ECPR Standing Group on the EU, Fourth Pan-European Conference on EU Politics, Riga, 25-27 September 2008. 
parliamentary contacts and non-state actors - frequent contacts form an indispensable aspect of a well-developed structural diplomacy.

The required long-term approach refers to the time dimension. Structural diplomacy is dependent on sustained diplomatic efforts: changing structures is a longterm process and therefore demands continued dialogue and follow-up. This also explains why this process of dialogue and negotiation can become institutionalized, either formally or informally. In this context, it is useful to emphasize that influencing or shaping structures within which actors operate can thus be harder and take more time than just influencing or changing actors' behaviour. However, if successful, the impact of such a structural diplomacy can be both more profound and more enduring.

The comprehensiveness that is required in structural diplomacy results from the close relationship between and interdependence of the various relevant structures (political, legal, social, economic and security structures) and levels (individual, societal, state, regional and global). Consequently, to be effective, structural diplomacy generally needs to focus simultaneously on various relevant structures and levels, and at least has to take into account the impact of structural changes on other levels or structures. Neglecting one or more relevant levels or sectors can undermine the achievements at other levels and structures. Here we can refer once again to efforts to promote democracy. As Linz and Stepan have argued, a structural change towards democracy cannot be successful when only focusing on the tenure of free and fair elections. ${ }^{20}$ In the absence of functioning rule of law structures or a civil society that is willing to participate in political democratic life, all diplomatic democratizing actions may fail in the long term. Another example is diplomatic actions that are aimed at promoting specific changes in the macroeconomic structures of a specific country. If one neglects to take into account the existing microeconomic structures and the societal level (for example, the patriarchal and/or self-sustaining agricultural nature of a society), diplomatic efforts are very likely to fail in the long term.

The factor of embeddedness points to the need for structural diplomacy to be embedded within a broader range of structural and traditional foreign policy initiatives. Structural diplomacy needs to be backed up by a broader structural foreign policy, which employs all instruments that are available and considered necessary in order to pursue the objective of structural changes (or of supporting existing structures) outside one's own borders. ${ }^{21}$ In order to be effective, the process of dialogue and negotiation needs to be complemented and supported by a process of technical, material, financial, economic and other assistance to the third country, in order to allow it to transform (or maintain) its structures practically. This assistance can vary from merely sending experts to assist in developing

20) Linz and Stepan, Problems of Democratic Transition and Consolidation.

21) Keukeleire and MacNaughtan, The Foreign Policy of the European Union, pp. 25-28 and 335-338. 
a judicial system, to carrying out comprehensive and long-term assistance programmes. As structural foreign policy aims to influence political, legal, social, economic and security structures on various levels, a wide and diverse range of instruments is needed according to the specific nature and requirements of each of these structures and levels. Besides providing assistance, structural diplomacy can also be supported, complemented or preceded by other types of foreign policy measures, including carrots (such as promising and providing major rewards or compensations) and sticks (threatening with or adopting coercive measures in cases where structural changes are blocked). However, as will be explained later, whereas these carrots and sticks can be quite instrumental in effectively influencing or shaping structures (the first key aspect of 'structural'), they can be detrimental in terms of these structures' sustainability (the second key aspect of 'structural').

When dealing with this factor of embeddedness within a broader foreign policy, we also need to stress the complementary nature of structural diplomacy and more traditional approaches to diplomacy. In those cases where inter-state relations are heavily disturbed by diplomatic or military crises and conflicts, these problems will reflect on the possible conduct of a structural diplomacy and will most probably overshadow the objective of structural changes. Western policy towards the Balkans since the early 1990s can illustrate this complementary (and even mutually dependent) relationship. Structural diplomacy towards the Balkans became possible only after successful traditional foreign policy actions and traditional diplomacy had taken place (including military operations and diplomatic negotiations leading to the peace agreements with Belgrade). However, the opposite is also correct: an enduring success of this traditional diplomacy could only be assured through subsequent structural diplomacy and the creation of a comprehensive set of new structures to make peace sustainable in the long term. Nevertheless, the relationship between structural and traditional objectives of diplomacy is not always unproblematic. The objective of promoting structural reforms in a third country or region can clash with other strategic interests, such as avoiding instability or chaos in that country/region or avoiding political tensions with the government of that country if this could be detrimental in terms of trade or energy supply.

The need for enduring and intensive efforts, along with the need for comprehensiveness and complementary foreign policy measures, points to the major challenges posed to an actor that wants to develop and sustain a structural diplomacy. First, the scope of the structural diplomacy and related structural foreign policy entails that political representatives and civil servants from specialized governmental agencies other than the Foreign Office - such as the ministries of internal affairs, justice, economics or finance - have to be taken on board in structural diplomacy initiatives (and potentially can also take structural diplomacy initiatives in their own right). It is obvious that this already leads to 
considerable problems with regard to coordination and common pooling of resources. Second, the magnitude of a structural diplomacy and structural foreign policy - and the considerable budget, resources and personnel needed for this policy - explain why developing a structural diplomacy is in general beyond the capacities of individual countries, with the exception of the most powerful global and regional powers and multilateral organizations. ${ }^{22}$ This indeed reveals the attractiveness of a broader multilateral framework to conduct structural diplomacy, as that would provide a useful arena to coordinate and organize diplomatic efforts and pool resources. Moreover, in view of the broad range of instruments available to them, international organizations such as the EU, the United Nations (UN), the International Monetary Fund (IMF) and the World Bank have a greater potential to conduct structural diplomacy than the majority of the world's countries.

The factor of legitimacy is related to the question of whether the structures that are promoted sufficiently take into account the existing (material and immaterial) situation in the third country. The crucial factor for sustainability is whether promoted structures are (or are becoming or remaining) part of the culture, mindsets, belief systems or mental structure of the people concerned (the general population as well as the elite). ${ }^{23}$ Structures or changes to structures will be (or become) internalized - and thus be more enduring - when they are seen as desirable and legitimate, and not just as the result of external pressure or a purely rational cost-benefit calculation (leading to acquiescence in order to avoid sanctions or gain economic support, for example). ${ }^{24}$ This also results in the hypothesis that a structural diplomacy that is based too much on a 'sticks and carrots' approach will have no sustainable results; and vice versa that a structural diplomacy is more likely to be successful if the promoted structures take into account, or are embedded within, endogenous traditions, preferences or processes in the target country, society or region..$^{25}$ This also means that the lower the legitimacy of a structural diplomacy, the more efforts and 'carrots' or 'sticks' are needed, but also the more limited the chances are of enduring effects.

\footnotetext{
22) However, this raises the question of whether the objectives of the structural diplomacy of the most important structural powers (such as the US, Russia, China and the EU) are compatible or competing. See Keukeleire and MacNaughtan, The Foreign Policy of the European Union, pp. 310-327.

23) See Martha Finnemore and Kathryn Sikkink, 'International Norm Dynamics and Political Change', International Organization, vol. 52, no. 4, 1998; Judith Goldstein and Robert O. Keohane (eds), Ideas and Foreign Policy: Beliefs, Institutions and Political Change (Ithaca NY: Cornell University Press, 1993); and Valerie M. Hudson (ed.), Culture and Foreign Policy (Boulder CO: Lynne Rienner, 1997).

24) Alexander Wendt, Social Theory of International Politics (Cambridge: Cambridge University Press, 1999), pp. 266-278.

25) This, however, gives rise to a set of other questions and conditions, such as the question of whether a consensus exists within that country or region on what structures and structural changes are indeed desirable and legitimate (see the examples of Belarus or the Palestinian Territories).
} 
This focus on legitimacy and mental structures is one of the reasons why structural diplomacy is 'a process of negotiation and dialogue'. It cannot only consist of negotiations, of putting pressure on other actors, and of actually convincing the other. The 'stronger' part of diplomacy needs to be accompanied by a dimension of dialogue. This dialogue has to precede and support negotiations, as this is crucial for understanding the endogenous processes and preferences of the target country, society or region and to understand how the structures promoted through structural diplomacy can take these into account. Moreover, it also implies that in order to be effective, this dialogue has to be a two-way and not just a one-way process, so that it can create a 'sense of ownership' of the structures. Although structural diplomacy implies a certain degree of inequality as it is about influencing structures towards one side's preferences, these aspects point to an important level of mutual dependency. The structural diplomacy concept therefore emphasizes the importance of 'communicative action in world politics', ${ }^{26}$ and also indicates that 'public diplomacy' can only contribute in a significant way to structural diplomacy if dialogue is taken seriously. ${ }^{27}$

\section{The Structural Diplomacy of the European Union}

It is not possible to provide a comprehensive assessment of the effectiveness of the EU's structural diplomacy within the scope of this article. This section, however, aims to assess whether the EU's institutional and diplomatic set-up and instruments allow it to develop a structural diplomacy. Does this set-up provide the adequate actors, instruments and framework to pursue structural objectives through diplomatic efforts? The next section will look briefly at how this set-up is put into practice in order to conduct structural diplomacy towards different regions of the world.

\section{The Institutional and Diplomatic Set-up of EU Structural Diplomacy}

Looking through a structural diplomacy lens instructs us to look beyond the traditional actors, procedures and instruments of diplomacy. It is important to keep in mind that EU diplomacy has a multi-pillar, multi-level and multi-location nature. ${ }^{28}$ First, diplomatic efforts are conducted through both the Union's first and second pillars, which are both characterized by their own specific actors,

\footnotetext{
26) Thomas Risse, 'Let's Argue! Communicative Action in World Politics', International Organization, vol. 54, no. 1, 2000, pp. 1-40.

27) See also Geoffrey Cowan and Amelia Arsenault, 'Moving from Monologue to Dialogue to Collaboration: The Three Layers of Public Diplomacy', The Annals of the American Academy of Political and Social Science, vol. 616, no. 1, 2008, pp. 10-30.

28) For a detailed analysis of the EU's institutional framework and policy-making system, see Keukeleire and MacNaughtan, The Foreign Policy of the European Union, pp. 66-123.
} 
procedures and instruments to perform structural diplomacy. Second, within the EU, the different member states continue to conduct their own diplomatic efforts vis-à-vis third countries. As a consequence of this multi-level character, member states are also able to conduct diplomacy through other international organizations - such as the UN, the North Atlantic Treaty Organization (NATO) and the Organization for Security and Cooperation in Europe (OSCE) - where non-EU actors and states also operate, where other procedures are in force and other instruments are available.

Diplomacy that emanates from both the first and second pillars is characterized by the involvement of multiple, highly diverse actors. Decision-making and implementation in many EU foreign policy domains involves - inter alia diplomats and civil servants from national ministries, the Presidency of the Council, diplomats and civil servants from the Council — including the High Representative and his staff, the Secretariat-General and the various entities of the European Security and Defence Policy (ESDP) - the European Commission, specialized EU agencies, and specialized governmental actors as well as non-governmental actors and representatives of 'civil society' (NGOs, professional organizations, research institutes and trade unions, etc.). Moreover, as structural diplomacy focuses on multiple structures that cover a wide array of sectoral issues, the sectoral substructures of these institutions and bodies - such as the various Directorates-General (DGs) of the European Commission, the sectoral Councils of Ministers and working groups, and the various sectoral ministries of the member states - are also involved in this process. Not only specialized national actors but also national cooperation and support programmes are called in to realize the objectives of the partnerships. This involvement of a wide range of actors makes the process complex and causes problems of coordination and consistency. Unfortunately, the Presidency of the Council, the High Representative for the Common Foreign and Security Policy (CFSP), the Council's Secretariat-General and the Commission are badly equipped to coordinate and support those multifarious actions and actors. ${ }^{29}$

It is useful to examine in more detail some of the afore-mentioned actors. In the early stages of the CFSP, as in the traditional diplomacy of states, the number of actors involved was more limited, and those actors were nearly always associated with the member states' ministries of foreign affairs. Successive treaty adaptations and the incremental institutionalization of CFSP and ESDP gradually increased the number and importance of the second pillar actors. The High Representative assists the Presidency, contributes to the formulation, preparation and implementation of CFSP decisions, and can conduct political dialogue with

29) For an analysis of the problem of coherence and consistency, see Simon Nuttall, 'Coherence and Consistency', in Christopher Hill and Michael Smith (eds), International Relations and the European Union (Oxford: Oxford University Press, 2005), pp. 91-112. 
third parties on behalf of the Council. The function of the High Representative provides the CFSP with a certain degree of visibility and continuity that facilitates the conduct of a 'traditional' diplomacy by the EU. The High Representative can rely on various entities within the Council's General Secretariat (with an increasingly important institutional set-up for the EU's ESDP operations) and on a growing number of EU Special Representatives who ensure continuity in the European Union's presence on the ground and who are also increasingly involved in structural diplomacy.

This is in particular the case in the Balkans, where the EU can rely on three Special Representatives: the EU Special Representative for the Former Yugoslav Republic of Macedonia (who also heads the European Commission delegation); the EU Special Representative for Bosnia and Herzegovina (who is also appointed High Representative for Bosnia and Herzegovina by the Steering Board of the Peace Implementation Council); and the EU Special Representative for Kosovo (who is also 'doubled-hatted' as the International Civilian Representative). ${ }^{30}$ The example of the EU Special Representative in Kosovo, Pieter Feith, demonstrates Special Representatives' central role in structural diplomacy. His mandate includes offering the EU's advice and support in the political process, thereby implementing the EU's policy objectives in Kosovo: developing a stable, viable, democratic and multi-ethnic Kosovo. He is also responsible for promoting overall EU political coordination in Kosovo, which is important in view of the activities of other EU actors in Kosovo. The European Commission Liaison Office in Kosovo implements assistance under the Instrument of Pre-Accession Assistance (IPA), which aims to strengthen Kosovo's economic structures. Also the EULEX Mission in Kosovo - comprising a large cohort of international police officers and judges - is clearly aimed at influencing structures with its objective of strengthening the rule of law.

However, the effectiveness of the diplomatic efforts of the High Representative, the Special Representatives and their staff depends on the mandate received from the Council and on the availibility of economic and financial instruments (largely controlled by the Commission) and civilian crisis-management instruments (largely controlled by the member states) to back up their diplomatic activities. Whereas this mandate is quite strong in the Balkans, with the necessary instruments being made available for the EU's Balkan initiatives, this is not at all the case for the EU's diplomatic actions in other parts of the world.

Even more important for the EU's structural foreign policy as a whole is the European Commission, which is responsible for the use of economic and financial instruments via support programmes and agreements with other regions and third countries. The Commission can rely on its administrative structure in Brussels, its extended diplomatic network in more than 120 states, and its experience

30) 'EU Special Representatives', Europa website at http://www.consilium.europa.eu. 
with and knowledge of the countries concerned. The Commission's extra advantage is that it is the only permanent EU partner with which third countries are used to negotiating and dealing. ${ }^{31}$ Within the Commission, various DirectoratesGeneral are involved in the development of comprehensive structural diplomacy. In addition to DG RELEX (External Relations and European Neighbourhood Policy), also the EuropeAid Cooperation Office and the DGs for Enlargement, Trade, Development and Humanitarian Aid play crucial roles. Specialized DGs - such as DG Justice, Freedom and Security, DG Energy and Transport, and DG Environment - can also play a role in elaborating and implementing specific dimensions of the EU's structural diplomacy.

The European Commission has played a crucial role in conceptualizing and developing the EU's structural diplomacy. Analysis of the preparations of most strategies and partnerships towards other regions since the mid 1990s shows that, to a large extent, it was the Commission that steered and concretized the development of those strategies and partnerships. The Commission contributed significantly in bringing to the surface the latent common interests of EU member states in stabilizing and restructuring other regions. Yet in most cases, the Commission's conceptual and substantial input has only been effective because it coincided with ambitions concerning the EU's external policy that were entertained especially by the member states. Particularly the large states, but also smaller states (for instance, Belgium with regards to the Democratic Republic of Congo), promote the development of an EU structural diplomacy towards specific regions or countries. They often consider this EU structural diplomacy as essential for supporting national structural diplomacy ambitions, which the EU member states on their own cannot materialize because of limited resources or in light of the magnitude and complexity of the structural changes. Member states contribute to an EU structural diplomacy through their national cooperation and support programmes, their own diplomatic efforts and network of bilateral contacts, their priviledged political, economic and military relationships with third countries, and their diplomatic representations in third countries. ${ }^{32}$

Because structural diplomacy does not aim at quick reactions to sudden external changes, but at pursuing long-term goals through comprehensive initiatives, the complexity and slow nature of policy-making under the Community method and the intergovernmental character of the CFSP/ESDP have not proved too much of an obstacle. Since structural diplomacy aims to reorganize and restructure the external environment, it is also of a largely regulatory nature, mirroring patterns of internal EC/EU policy-making. As a by-product of the complex

\footnotetext{
31) See also Michael Bruter, 'Diplomacy Without a State: The External Delegations of the European Commission', Journal of European Public Policy, vol. 6, no. 2, 1999, pp. 183-205; and Simon Duke, 'Preparing for European Diplomacy?', Journal of Common Market Studies, vol. 40, no. 5, 2002, pp. 849-870.
}

32) Keukeleire and MacNaughtan, The Foreign Policy of the European Union, pp. 52-54. 
decision-making process, the resulting objectives that the European Union has defended in its external activities have incorporated many different interests, and have inserted themselves more and more in a long-term strategic perspective. ${ }^{33}$

\section{EU Instruments and Capabilities}

Various diplomatic, political and economic-financial instruments play a role in the EU's structural diplomacy. Central are the negotiations, meetings and 'political dialogue' with third countries and other regions in the framework of cooperation or association agreements. ${ }^{34}$ This interaction not only extends across themes of foreign and security policy and political matters, but also includes a wide spectrum of first and third pillar policies. These agreements emanate from all three pillars, and encompass trade, development cooperation, economic, financial and technical cooperation and foreign and security policy, in addition to other policy fields. The scope and depth of issues that are subject to cooperation varies substantially. Agreements provide for cooperation in various socio-economic fields and in a host of other areas of interest, including, for example, migration, justice and home affairs issues, foreign and security policy, drugs, science, culture, energy or the environment. They can also provide for support to the political structures of a country or region (such as capacity-building of state institutions, good governance and rule of law).

Important in this context is the aspect of conditionality, which means the practice of making the conclusion and implementation of agreements, cooperation and assistance dependent on certain conditions being met. Since the mid-1990s, almost all EU agreements contain a human rights clause and often also provisions to make respect for democratic principles and the rule of law essential elements of the agreement. Concluding or refusing to conclude agreements with third states can be a trump card that the EU uses to reward (or sanction) countries when they pursue (or refuse) structural reforms. ${ }^{35}$

Each cooperation and association agreement creates an institutional framework through the provisions for 'institutions of the agreement ${ }^{36}$ as well as through the regular meetings foreseen for political dialogue. Contacts touch on all sectors

\footnotetext{
33) Keukeleire and MacNaughtan, The Foreign Policy of the European Union, pp. 204-215.

34) For the relevance of the EU's first pillar policies and their impact on foreign policy, see Jan Orbie (ed.), Europe's Global Role: External Policies of the European Union (Aldershot: Ashgate, 2008); and Stephan Stetter, EU Foreign and Interior Policies: Cross-Pillar Politics and the Social Construction of Sovereignty (London: Routledge, 2007).

35) Piet Eeckhout, External Relations of the European Union: Legal and Constitutional Foundations (Oxford: Oxford University Press, 2004), pp. 475-481. See also Elena Fierro, The EU's Approach to Human Rights Conditionality in Practice (The Hague: Martinus Nijhoff, 2003).

36) For example, the Euro-Med Association Agreement with Morocco provides for an Association Council (ministerial level), an Association Committee (official level) and various subcommittees (including one on human rights, democratization and governance).
} 
of the economy and government, and thus also include meetings of specialized ministers, civil servants and, in some agreements, also members of parliament. The 'political dialogue' meetings are devoted both to more traditional aspects of diplomacy (such as bilateral relations, international issues of mutual concern, security issues and conflicts) and to structural objectives (with an emphasis on the reinforcement of democratic structures, promotion of human rights and rule of law). Every year there are around 150 'political dialogue' meetings on a head of state or government, ministerial or senior official level with 50 third countries and with the member states of 20 regional organizations. ${ }^{37}$

In view of their longer time perspective and the broad scope of policy fields involved, the cooperation and association agreements, at least on paper, can provide a firm basis for structural diplomacy. They can be instrumental in supporting or inducing structural reforms, or in strengthening existing political, legal and socio-economic structures in third countries and regions - with conditionality and political dialogue instruments providing further support to this dynamic. By forming joint institutions and including political dialogue in the bilateral relations, a potentially powerful instrument of structural diplomacy is created. However, in practice, the objectives of structural diplomacy often compete or collide with other priorities and interests. EU representatives and member states often prioritize trade and cooperation issues and do not like to disturb negotiations on these issues by tough talks on structural reforms. The result is that political dialogue is often not exercised to its full potential.

Cooperation agreements and association agreements also provide the setting through which the EU channels its very substantial financial aid. When political dialogue and agreements produce results, it is often because they are closely connected to the financial instruments of the first pillar, which is in fact the true basis of the EU's leverage. Within the EU's financial framework for the period 20072013, 5.7 per cent (or €53.3 billion) of the EU's budget has been devoted to 'the EU as a Global Partner'. The most important are the Instrument for Pre-Accession (IPA), the European Neighbourhood and Partnership Instrument (ENPI) and the Development Cooperation Instrument (DCI), which receive in total nearly 40 of these $€ 53.3$ billion. ${ }^{38}$ The IPA covers EU candidate countries and potential candidate countries. It provides wide-ranging economic and financial assistance, and supports countries in fulfilling the political and economic requirements of EU accession. In the Balkans it also supports confidence-building programmes, stabilization, regional cooperation and institution-building. ENPI covers countries targeted by the European Neighbourhood Policy (ENP - the

\footnotetext{
37) Council of the European Union, CFSP Instruments (Legislative Acts, Declarations, Demarches, Heads of Mission Reports and Political Dialogue Meetings) - 2006, 6233/07, 2007.

38) For the period 2007-2013, the IPA receives almost $€ 11.5$ billion, the ENPI about $€ 11$ billion, and the DCI approximately $€ 17$ billion; see European Commission, Financial Programming 2007-2013 (plus Annexes), 2007.
} 
former Soviet republics in Eastern Europe and the Southern Caucasus, and the Mediterranean) and the EU's partnership with Russia. ENPI provides financial backing for activities under the EC's bilateral agreements with these countries and focuses in particular on supporting the implementation of ENP action plans. The DCI covers developing countries, territories and regions that are not eligible for assistance under the two previous instruments. It supports development cooperation, economic and financial cooperation, and has poverty reduction as one of its main objectives. Cooperation under the Cotonou Agreement with the ACP countries (the group of African, Caribbean and Pacific countries, mainly in subSaharan Africa) is funded through the separate European Development Fund (EDF), which is based on separate contributions by member states, with the tenth EDF for the period 2008-2013 amounting to $€ 22.7$ billion. The EDF is mainly focused on poverty reduction, although attention for influencing political structures is gradually growing. Besides these major financial instruments, the budget also contains some other budget lines that are relevant for the EU's structural diplomacy, such as the European Instrument for Democracy and Human Rights (EIDHR) and the Instrument for Stability (IFS). However, in terms of financial weight, these instruments are much less significant. ${ }^{39}$

Economic-financial instruments may have a direct impact through the support of economic reforms and economic development, or through making financial means available for political or organizational change, such as for free elections or for such structural reforms as the development of a new judicial structure or training police units along Western lines. The instruments may also have an indirect impact, as the promise of economic-financial support or cooperation may be used by the EU as a leverage to promote or enforce political and social reforms (such as the organization of free elections, respect for the rights of ethnic minorities, etc.).

The EU's structural diplomacy can also increasingly rely on the growing capacities in the second pillar and the ESDP in particular. ${ }^{40}$ This is not only related to active involvement by the High Representative and the Special Representatives in structural diplomacy (particularly in the Balkans). During the past decade, in the framework of the various Civilian Headline Goals, the European Union has developed its capabilities for civilian crisis management in the fields of the police, strengthening the rule-of-law sector, strengthening civilian administration and monitoring capability. ${ }^{41}$ This means that more traditional diplomatic initiatives can increasingly be complemented by civilian missions, such as for developing

\footnotetext{
39) Keukeleire and MacNaughtan, The Foreign Policy of the European Union, pp. 116-118.

40) See Jolyon Howorth, Security and Defence Policy in the European Union (Basingstoke: Palgrave Macmillan, 2007).

41) EU Council Secretariat, European Security and Defence Policy: The Civilian Aspects of Crisis Management, Factsheet, civ/02, June 2008.
} 
security structures in the country or region concerned. ${ }^{42}$ In the field of police reform and rule of law, the EU has already implemented or is still involved in several missions, especially in the Balkans (such as EULEX in Kosovo) and the Democratic Republic of Congo (such as the EU's police mission in Kinshasa). ${ }^{43}$

This brief assessment of the EU's institutional set-up and its instruments seems to indicate that it does indeed provide the necessary elements to conduct structural diplomacy. A wide and diverse array of actors is involved in the EU's diplomatic efforts, which possesses a considerable basket of technical, material, financial, economic and other instruments to support structural diplomatic efforts. However, the extent to which diplomatic efforts are indeed characterized by structural objectives, and to what extent these structural diplomatic efforts are effective, does vary strongly depending on the region involved. The next section will briefly assess the EU's structural diplomacy towards the Central and Eastern European countries (CEECs), the Balkans, the Mediterranean area and the countries that are part of the EU's European Neighbourhood Policy, and sub-Saharan Africa.

\section{The EU's Structural Diplomacy: Objectives and (Lack of) Achievements}

The inclusion of ten neighbouring Central and Eastern European countries into the EU in 2004 and 2007 concluded one of the EU's most significant foreign policy achievements. The diplomacy conducted by the EU towards these countries in the years leading to their accession can definitely be considered structural, as it aimed to overhaul completely the existing rules of the games and reshape the countries to fit within EU structures of free market, democracy, rule of law and human rights. With the CEECs (and to a varying degree also with the countries of the Balkans), the EU could play its trump card: the prospect of accession. This prospect of and preparation for EU membership not only provided a framework for the desired structural changes, but was also the ultimate reward (or 'carrot') offered to these countries. ${ }^{44}$ However, these regions and the EU's policy towards these countries also had other characteristics: all EU member states considered structural changes in Central and Eastern Europe and in the Balkans as in their interest and also accepted the costs related to the successful promotion of these structural changes; the EU was able to take a long-term approach; the EU could

\footnotetext{
42) See Agnieszka Nowak, Civilian Crisis Management: The EU Way, Chaillot Papers, no. 90 (Paris: EU Institute for Security Studies, 2006).

43) International Security Information Service Europe, 'ESDP and EU Mission Update - December 2008', European Security Review, no. 42, 2008, pp. 25-26.

44) See also Heather Grabbe, The EU's Transformative Power: Europeanization through Conditionality in Central and Eastern Europe (Basingstoke: Palgrave Macmillan, 2006); Frank Schimmelfennig, S. Engert, and H. Knobel, International Socialization in Europe: European Organizations, Political Conditionality and Democratic Change (Basingstoke: Palgrave MacMillan, 2006); and Jan Zielonka, Europa as Empire: The Nature of the Enlarged European Union (Oxford: Oxford University Press, 2006).
} 
tackle all structures in a comprehensive and consistent manner, while establishing benchmarks for measuring their successes and compliances; the structures that the EU was promoting were embedded in endogenous processes; and the traditional foreign policy problems were tackled by other actors (such as NATO) or gradually diminished as a result of the Europeanization and socialization processes. Moreover, the EU was particularly able in this case to address the mental structures of the target region, as a large majority of the elites and population wanted change. While the costs associated with these changes might not have been palatable, they were accepted because the end goal was firmly rooted in the popular consciousness. These factors meant that the countries of Central and Eastern Europe more or less met the conditions for a 'successful' structural diplomacy in a way that has not been mirrored in the other regions of the world discussed here.

Whereas relations with the new member countries were fully based on the 1993 Copenhagen criteria, the cornerstone of the EU's policy towards the Balkans is the Stabilization and Association Process (SAP) ${ }^{45}$ Launched in 1999, the SAP is based on a progressive partnership with each country, in which the EU offers a mixture of contractual relationships through the Stabilization and Association Agreements (SAA) ${ }^{46}$ (which govern the political, trade and economic relations of the EU with the Balkan countries) and substantial economic and financial assistance (through the Instrument for Pre-Accession, which in 2007 replaced the CARDS programme - Community Assistance for Reconstruction, Development and Stabilization). ${ }^{47}$ With this policy, the EU has gone beyond the common elements of conditionality that governed its pre-accession relations with the CEECs (democracy, rule of law, human rights and market economy reforms). The EU is increasingly effective in fostering structural change in the Balkans. It has added further conditions related to the Balkans' specific post-war situation and the need to overcome regional antagonism. However, a range of factors within both the EU and the Balkan region indicates that this transformation will continue to be a difficult process. Enthusiasm among EU member states for further EU enlargement has seriously diminished, thereby also undermining the impact of the 'accession carrot'. Levels of inter-state and intra-state animosity remain high, and while restoring war-damaged infrastructure is relatively straightforward, rebuilding economic structures and particularly repairing the societal and psychological damage of war is far from it. In conjunction with 45 years of communist rule that only

\footnotetext{
45) See Kolinda Grabar-Kitarovic, 'The Stabilization and Association Process: The EU's Soft Power at Its Best', European Foreign Affairs Review, vol. 12, no. 2, 2007, pp. 121-125.

46) Commission of the European Communities, Communication on the Stabilization and Association Process for Countries of South-Eastern Europe, $\operatorname{COM}(1999) 235$. The SAA are concluded with the South-Eastern European countries separately.

47) Council of the European Union, Council Regulation 1085/2006 establishing an Instrument for PreAccession Assistance (IPA), OJ L 210, 31 July 2006.
} 
ended in 1991, it is clear that the adaptation of mental structures and interiorization of the new rules of the game, which are essential elements for a structural diplomacy to have significant impact, remain a very real challenge in this region. This is particularly the case in Kosovo, which is now the subject of the EU's most comprehensive structural diplomacy, with not only the EULEX mission, but also many other EU instruments at play, ranging from large-scale financial support through the Commission's IPA funds to so-called twinning projects - wherein local administrations in Kosovo are supported by local administrations within the EU to exchange best practices. ${ }^{48}$

In the mid-1990s, the European Union wanted to apply the objectives and methodology that had proven so successful with its Eastern neighbours to its relations with the Mediterranean. The EU envisaged fundamental changes in the political, legal, economic and societal structures within individual Mediterranean countries, in their mutual relations and in their relations with the EU. However, in this case the EU could not play its trump card - the prospect of accession. ${ }^{49}$ The ground-breaking Euro-Mediterranean Conference of 1995 in Barcelona brought together for the first time foreign ministers of the EU member states with their colleagues from the Maghreb, the Middle East and Cyprus, Malta and Turkey. The Barcelona Conference established the Euro-Mediterranean Partnership (EMP $)^{50}$ and laid the foundations for a process that was designed to build a comprehensive multilateral framework for dialogue and cooperation in the three dimensions of the partnership: the political and security partnership; the economic and financial partnership; and the partnership in social, cultural and human affairs. Despite its limitations and ambiguities, the EMP looked promising: it focused on genuine structural reforms, was comprehensive in nature and could rely on a wide set of policy instruments. However, despite the intrinsic value of this unique institutionalized framework for Euro-Mediterranean dialogue and cooperation, disappointment overshadowed the tenth anniversary of the Barcelona Process. Although the structural diplomacy dimension was strong in both intentions and the set-up of the EMP, it was weak in terms of impact, as it has not acted as a motor for far-reaching structural change. This failure was a hard lesson for the EU: that pursuing a long-term and comprehensive structural diplomacy, without being able to provide an answer to the traditional diplomacy challenge of the Middle East peace process, was impossible. Furthermore, the

\footnotetext{
48) See, for example, D. Papadimitriou, 'To Build a State: Europeanization, EU Actorness and StateBuilding in Kosovo', European Foreign Affairs Review, vol. 12, no. 2, 2007, pp. 219-238.

49) For a comparison of the EU's Eastern and Mediterranean policies, see Marc Maresceau and Erwan Lannon (eds), The EU's Enlargement and Mediterranean Strategies: A Comparative Analysis (Basingstoke: Palgrave Macmillan, 2001). See also H.A. Fernandez and Richard Youngs (eds), The Euro-Mediterranean Partnership: Assessing the First Decade (Madrid: FRIDE - Real Instituto Elcano, 2005).

50) Commission of the European Communities, Strengthening the Mediterranean Policy of the European Union: Establishing a Euro-Mediterranean Partnership, Communication COM(1994) 427.
} 
effectiveness of the EU's structural diplomacy towards this region was rather problematic because its objectives were not supported to the same degree by endogenous processes and forces as has been the case in Central and Eastern Europe and, in particular, because they are not shared by the ruling elites in these countries. More fundamentally, it is also no clearer whether EU countries still really want structural reforms in the Mediterranean area, as structural changes may lead to unforeseen and unfavourable outcomes that might not be in the EU's interest - such as the coming to power of Islamist parties (such as Hamas in the Palestinian Territories) and a growing structural influence of political Islam in general. ${ }^{51}$

These explanations for the failure of the Barcelona Process are relevant in assessing the EU's attempts to upgrade and 'rescue' the Euro-Mediterranean Partnership through the European Neighbourhood Policy (ENP), which was launched in 2004. ${ }^{52}$ The ENP includes the Mediterranean countries as well as the Commonwealth of Independent States (CIS) countries - Ukraine, Moldova and the countries of the South Caucasus - that are situated within the Russian 'near abroad'. ${ }^{53}$ Even if endogenous support for structural change exists among the political and economic elites of some of these ENP countries, this support is not the case for all partners. Also, in the handful of countries with a (moderately) reformist leadership, endogenous public support for modernization, liberalization and 'Western' reforms appears to be fading among some sections of society, with support for the competing Islamic — or Russian, in the case of the CIS countries - structures increasing. A problem for the sustainability and legitimacy of the EU's ENP strategy is that the EU has once again failed to pay sufficient attention to the immaterial dimension, to the societal and human security dimension, and to the interests of its partners. ${ }^{54}$

Prospects for the latest two EU initiatives with regard to the ENP region do not look much better. The Union for the Mediterranean ${ }^{55}$ - the ambitious project launched by French President Sarkozy in July 2008 — risks meeting the same fate as the preceding initiatives. The Union for the Mediterranean is categorized under the Barcelona Process and aims to increase joint ownership of the Euro-

\footnotetext{
51) See Michael Emerson and Richard Youngs (eds), Political Islam and European Foreign Policy: Perspectives from Muslim Democrats of the Mediterranean (Brussels: Centre for European Policy Studies, 2007).

52) Commission of the European Communities, European Neighbourhood Policy: Strategy Paper, Communication COM (2004)373.

53) See Laure Delcour and Elsa Tulmets, 'Special Issue: Is the European Union an International Actor in the Making? The Neighbourhood Policy as a Capability Test', European Political Economy Review, no. 7, summer 2007. For a detailed analysis of EU-CIS-Russia relations, see Katlijn Malfliet, Lien Verpoest and Evgueny Vinokurov (eds), The CIS, the EU and Russia: Challenges of Integration (Basingstoke: Palgrave Macmillan, 2007).

54) See also Federica Bicchi, “'Our Size Fits All”: Normative Power Europe and the Mediterranean', Journal of European Public Policy, vol. 13, no. 2, 2006, pp. 286-303.

55) Commission of the European Communities, Barcelona Process: Union for the Mediterranean, Communication COM(2008)319.
} 
pean Union and Mediterranean countries. The concrete projects that are incorporated in the proposal are, however, mainly symbolic and cannot be expected to provide the necessary leverage to boost structural reforms. With regard to the countries of Eastern Europe and the Southern Caucasus, in late 2008 the European Commission launched a proposal for a new Eastern Partnership. ${ }^{56}$ With this new partnership, which comprises a substantial increase in the EU's budget towards this region, the EU aims to intensify the level of mutual political engagement and economic convergence of these countries with the EU's economy, within the framework of a new generation of association agreements and much more institutionalized support for domestic reforms. However, it remains to be seen how this Eastern Partnership will be further elaborated and whether it will be able to make a difference in terms of promoting structural reforms.

Since its signing in 2000 and entering into force in 2003, relations with subSaharan Africa are mainly organized through the Cotonou Agreement with the ACP countries,${ }^{57}$ and, also since 2003 , gradually through the use of second pillar instruments. The Cotonou Agreement brought about three main developments in comparison with the preceding Lomé Agreements. ${ }^{58}$ First, economic liberalization now prevails in the trade provisions. A second major development was the provision for broadening the participation of civil society, local actors and the private sector, hereby aiming to increase the feeling of 'ownership'. A third innovation is the more prominent place of the promotion of political elements such as human rights, democracy and the rule of law on the agreement's agenda. However, even after the changes introduced by the Cotonou Agreement, EU policy towards Africa was a far cry from the structural foreign policy that it had developed and implemented vis-à-vis its neighbouring countries. With the EU's Strategy for Africa of 2005, the structural diplomacy implied in the conclusion of the Cotonou Agreement seems to have become better supported by some necessary and complementary instruments. ${ }^{59}$ The question remained of whether the joint strategy would manage to substantiate further the new focus in the Cotonou Agreement by directing the required financial resources to support the desired structural changes. A second factor that hinders the success of structural diplomacy towards sub-Saharan Africa is the EU's perceived paternalist or neo-colonial attitude, allowing no space for a real two-way dialogue and engagement in real 'communicative action'. A third problem is the multitude of crises and conflicts in Africa. Despite a growing engagement, the scale of the EU's involvement in

\footnotetext{
56) Commission of the European Communities, Eastern Partnership, Communication COM (2008) 823.

57) Partnership Agreement between the African, Caribbean and Pacific Group of States (ACP), on the one side, and the European Community and its member states, on the other, signed in Cotonou on 23 June 2000, OJ L 195, 1 August 2000.

58) Martin Holland, The European Union and the Third World (Basingstoke: Macmillan, 2002), p. 219.

59) Commission of the European Communities, EU Strategy for Africa: Towards a Euro-African Pact to Accelerate Africa's Development, Communication COM (2005) 489, p. 2.
} 
these traditional diplomatic challenges is limited, both in terms of geographical coverage and in terms of scope. Considering these problems, it can be concluded that the achievements of the EU's structural diplomacy towards sub-Saharan Africa remain limited to intentions and, to some extent, set-up. However, in terms of real impact, results remain very limited.

\section{Conclusion}

This article develops the concept of 'structural diplomacy', which is defined as the process of dialogue and negotiation by which actors in the international system seek to influence or shape sustainable and external political, legal, economic, social and security structures at different relevant levels in a given geographic space. This concept - which complements other new conceptualizations of diplomacy - brings to the fore that diplomacy is not only focused on inter-state relations, conflicts and crises, but is increasingly concerned with influencing and shaping structures: the organizing principles, rules of the game and institutions that directly or indirectly determine how actors behave and relate to each other in the longer term. The qualification structural not only refers to the objective of having an effect on structures, but also on having effects that are sustainable. The effectiveness of a structural diplomacy depends on various factors, including intensity, long-term approach, comprehensiveness, embeddedness within broader structural and traditional foreign policy initiatives, and legitimacy. These factors indicate that developing a structural diplomacy is in general beyond the capacities of most diplomatic actors (with the exception of global and regional powers), which is why multilateral frameworks provide a useful arena to organize diplomatic efforts and pool resources.

It is in this context that analysis of the European Union is relevant. This article indicates that the EU can rely on a wide array of institutional actors and instruments from both the first and second pillars to develop structural diplomacy. A variety of institutional actors are involved in the EU's structural diplomacy, including not only traditional diplomatic actors (such as the High Representative, the Special Representatives and the various bodies involved in civilian ESDP operations), but also the various sectoral DGs of the European Commission (which can rely on their longstanding experience and authority over important first pillar instruments). Instruments that — at least on paper — allow the EU to develop a structural diplomacy include the wide range of association and cooperation agreements (and the related instrument of conditionality), considerable financial resources, development cooperation, political dialogue, peace-building instruments and - more recently - civilian crisis-management capabilities. In practice, however, the extent and effectiveness of the EU's structural diplomacy vary strongly depending on the region involved, as became clear from the brief 
assessment of the EU's structural diplomacy towards the CEECs, the Balkans, the Mediterranean area, the ENP countries and sub-Saharan Africa. This overview also pointed to the relevance of the various factors that determine the success of a structural diplomacy.

Finally, further theoretical and empirical research is needed to develop and strengthen further the concept 'structural diplomacy' as a tool to analyse diplomacy in general and the diplomatic efforts of the EU and other international actors. Possible research topics include the relationship between structures and sustainability, the factors that affect effectiveness (and the relative importance of material and immaterial factors), the relationship between traditional and structural diplomacy, and the relationship between structural diplomacy and other new conceptualizations of diplomacy. Empirical research on the structural diplomacy of the EU can include detailed assessments of the EU's structural diplomacy towards the various regions, the factors that determine both the development and success of the EU's structural diplomacy, and the role of the EU's various institutional actors and pillars. Research can also focus on the structural diplomacy of other international actors (such as the United States, Russia and China), including a comparative assessment of the structural diplomacy of the world's major powers.

Stephan Keukeleire is Jean Monnet Professor in European Foreign Policy at the Institute for International and European Policy of the Catholic University of Leuven, a member of the Leuven Centre for Global Governance Studies and visiting Professor at the College of Europe, Bruges, Belgium. Keukeleire's research focuses on various dimensions of (European) foreign policy: the conceptualizing and analysis of (European) foreign policy in the twenty-first century; structural foreign policy; inter-pillar foreign policy in the EU; the CFSP; and the role of networks and contact groups in EU foreign policy. He has written books and articles on European foreign policy, European security and European institutions and decision-making, including (together with Jennifer MacNaughtan) The Foreign Policy of the European Union (Basingstoke: Palgrave, 2008).

Robin Thiers is a Research Fellow at the Institute for International and European Policy of the Catholic University of Leuven in Belgium and is Coordinator of the Jean Monnet Centre of Excellence in Leuven. As a $M A$ student he conducted research on the role of the OSCE in the democratization of Armenia. He is currently conducting research for his Ph.D. on the EU's policies in Kosovo in the field of the rule of law.

Arnout Justaert is a Research Fellow at the Institute for International and European Policy of the Catholic University of Leuven in Belgium. His research interests include the European Union's foreign policy (CFSP and ESDP) and European policy-making. He is currently conducting research for his Ph.D. on networks and governance in EU foreign policy towards the Democratic Republic of Congo. 